\title{
Volatile Composition and Cytotoxic Activity of Aerial Parts of Crassocephalum crepidioides growing in Western Himalaya, India
}

\author{
SONI THAKUR¹, R. KOUNDAL ${ }^{1}$, D. KUMAR², A. K. MAURYA¹, Y. S. PADWAD², B. LAL ${ }^{3}$ AND V. K. AGNIHOTRI ${ }^{1 *}$
}

Academy of Scientific and Innovative Research, ${ }^{1}$ Natural Product Chemistry and Process Development Division, ${ }^{2}$ Division of Food and Nutraceuticals, ${ }^{3}$ Biodiversity Division, CSIR-Institute of Himalayan Bioresource Technology, Palampur-176 061, India

Thakur et al.: Volatile Composition and Cytotoxic Activity of Crassocephalum crepidioides

The composition of the essential oil of Crassocephalum crepidioides was characterized using retention indices, gas chromatography-mass spectrometry and quantified by gas chromatography-flame ionization detector. Twenty seven components were identified, representing $91.2 \%$ of the total oil. The essential oil of Crassocephalum crepidioides was dominated by monoterpene hydrocarbons $(80.9 \%)$ with $\beta$-myrcene 
(65.9 \%), $\beta$-phellandrene (8.8 \%), $\alpha$-pinene (3.1 \%) and sesquiterpene hydrocarbons (4.8 \%) with $\alpha$-copaene $(1.5 \%)$, and $\alpha$-humulene (1.5\%). Promising essential oil yield with $\beta$-myrcene as major component, suggests that crop could be considered for commercial cultivation. The obtained essential oil was tested against human cervical cancer SiHa, human oral epidermal carcinoma KB and human adenocarcinoma Colo-205 cell lines at $48 \mathrm{~h}$, which showed significant results against all cell lines $(59.8 \pm 3.7,67.9 \pm 0.5$ and $84.5 \pm 3.6$, respectively at $100 \mu \mathrm{g} / \mathrm{ml})$.

\section{Key words: Asteraceae, Crassocephalum crepidioides, $\beta$-myrcene, $\beta$-phellandrene, cytotoxicity}

The genus Crassocephalum belongs to Asteraceae family is widely distributed in the tribe Senicioneae and represented by approximately 100 species in Asia, Africa, Australia, Malaysia, China, Nepal and Sri Lanka. Many of these species are widely used as food additives or in traditional medicines ${ }^{[1,2]}$. Crassocephalum crepidioides commonly known as thickhead or fireweed and used as oriental medicine for the treatment of cut and to cure diarrhoea ${ }^{[3]}$. C. crepidioides used as a vegetable and was reported to have high nutritional values ${ }^{[4]}$. The plant parts have been used to treat fever, liver disorders such as hepatitis, indigestion and also as purgative and laxative. It has antioxidant, antiinflammatory, antitumor and antibacterial properties ${ }^{[3-5]}$. Phytochemical screening of this plant recorded the presence of alkaloids, diterpenes, tannins, coumarins, flavonoids, mucilage, reducing compounds and steroids ${ }^{[1,2,5]}$. The essential oil of $C$. crepidioides was earlier reported in literature from Western Ghat region of North West Karnataka, India, elevation $800 \mathrm{~m}^{[6]}$.

In continuation of our bioprospection program ${ }^{[7-9]}$, the aim of present study was to carry out chemical composition analysis and cytotoxic activity of the flowering aerial part essential oil of $C$. crepidioides growing in the Western Himalayan region (1372 m, asl). To the best of our knowledge, this is the first report on the chemical composition and cytotoxic activity of the essential oil from this plant growing in western Himalayan region of Himachal Pradesh, India.

Fresh plant material of $C$. crepidioides was collected from the farm land of CSIR-IHBT (India, elevation $1372 \mathrm{~m}$ ) situated in the Western Himalaya. Plant material was characterized by the taxonomist of the institute and a voucher specimen deposited at CSIRIHBT Herbarium, Palampur, India (voucher no. PLP_17618; fig. 1).
Fresh plant material $(3.2 \mathrm{~kg})$ of $C$. crepidioides was hydrodistilled for $3 \mathrm{~h}$ to obtain essential oil using Clevenger type apparatus. The hydrodistillation was performed in triplicate with the help of $5000 \mathrm{ml}$ heating mantle, $5000 \mathrm{ml}$ round bottom flask and a condenser. The obtained essential oil was dried over anhydrous sodium sulphate and stored at low temperature until used for gas chromatography/gas chromatographymass spectrometry (GC/GC-MS) analyses.

Analysis of the composition of the essential oil was carried out with the help of a GC on Shimadzu GC 2010 equipped with DB-5 (J and W Scientific, Folsom, CA, USA) fused silica capillary column $(30 \times 0.25 \mathrm{~mm}$ id, $0.25 \mu \mathrm{m}$ film thickness) and a flame ionization detector. The GC oven temperature program used was as follows, $70^{\circ}$ (initial temperature) held for $4 \mathrm{~min}$, increased at a rate of $4^{\circ} / \mathrm{min}$ to $220^{\circ}$ and held for $5 \mathrm{~min}$. Injector temperature $240^{\circ}$, detector temperature $260^{\circ}$, injection mode, split. Carrier gas was nitrogen at column flow rate of $1.05 \mathrm{ml} / \mathrm{min}(100 \mathrm{kPa})$. The GC oven temperature was $70^{\circ}$ for $4 \mathrm{~min}$ and then to $220^{\circ}$ at $4^{\circ} / \mathrm{min}$ and held for $5 \mathrm{~min}$. Injector temperature, $240^{\circ}$; interface temperature, $250^{\circ}$; acquisition mass range, 800-50 amu; ionisation energy, $70 \mathrm{eV}$. Helium was used as carrier gas.

All individual essential oil constituents were identified on the basis of their GC retention indices (RI) determined using homologous series of $n$-alkanes $\left(\mathrm{C}_{9}-\mathrm{C}_{21}\right)$ on the DB-5 capillary column and using library search of National Institute of Standards and Technology database ${ }^{[10]}$ as well as by comparing their

This is an open access article distributed under the terms of the Creative Commons Attribution-NonCommercial-ShareAlike 3.0 License, which allows others to remix, tweak, and build upon the work non-commercially, as long as the author is credited and the new creations are licensed under the identical terms

Accepted 26 November 2018

Revised 24 April 2018

Received 09 March 2017 Indian J Pharm Sci 2019;81(1):167-172 


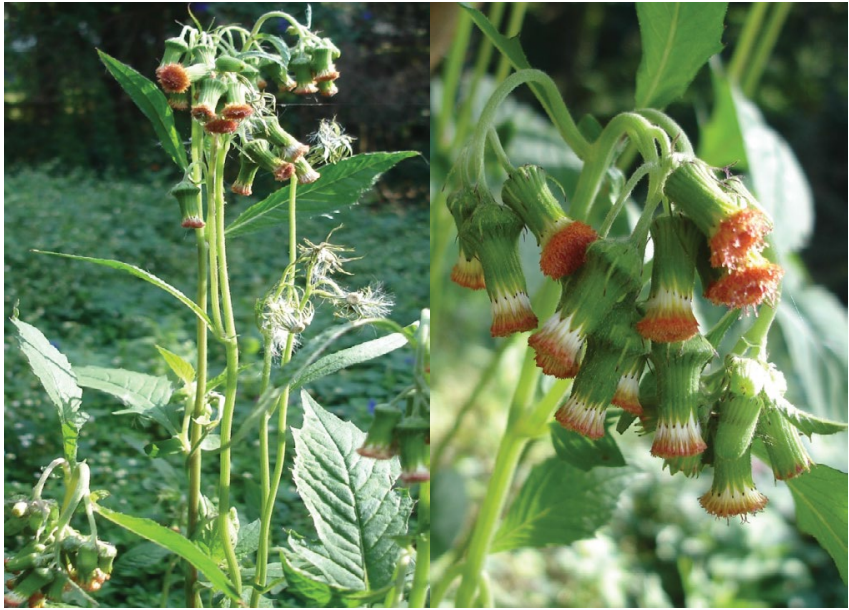

Fig. 1: Crassocephalum crepidioides (Benth.) S. Moore (Asteraceae) red flower ragleaf

Plant growing in nature and collected from CSIR-IHBT campus $(1300 \mathrm{~m})$, a part of Indian western Himalaya. A: a plant with green, serrated, elliptical leaves, cylindrical heads and silky seeds; B. inflorescence showing heads with orangereddish florets

mass spectral fragmentation pattern with those reported in literature ${ }^{[11]}$. Identification of major components were also confirmed by ${ }^{13} \mathrm{C}$ nuclear magnetic resonance (NMR) spectra by comparing with literature ${ }^{[12,13]}$.

Human cervical cancer ( $\mathrm{SiHa}$ ), human oral epidermal carcinoma $(\mathrm{KB})$ and human adenocarcinoma (Colo205) cells were obtained from the National Animal Cell Culture repository at National Centre for Cell Science, Pune, India. SiHa and KB Cells were grown in Dulbecco's modified Eagle medium (Invitrogen Biosciences) whereas Colo-205 cultured in F-12 HAMS (Invitrogen Biosciences) medium, supplemented with $10 \%$ heat-inactivated fetal bovine serum (Invitrogen Biosciences) and $1 \%$ antibiotic antimycotic (Invitrogen Biosciences). The cells were maintained at $37^{\circ}$ with $5 \% \mathrm{CO}_{2}$ and $95 \%$ humidified atmosphere in a $\mathrm{CO}_{2}$ incubator ${ }^{[14,15]}$.

The cells were trypsinised and washed twice with phosphate-buffered saline and incubated at a density of $2 \times 10^{4}$ cells/well in flat-bottom 96-well plates in $100 \mu \mathrm{l}$ of complete medium. Several concentrations $(10,25$, 50 and $100 \mu \mathrm{g} / \mathrm{ml}$ ) of oil in $100 \mu \mathrm{l}$ complete medium were added. Vinblastine $(1 \mu \mathrm{M})$ was used as positive control, whereas cells alone supplemented with complete medium were used as negative control. Plates were incubated at $37^{\circ}$ for $48 \mathrm{~h}$ in a $\mathrm{CO}_{2}$ incubator. After incubation period, $50 \mu \mathrm{l}$ of $50 \%$ trichloroacetic acid (Merck) was added and plates were incubated at $4^{\circ}$ for $1 \mathrm{~h}$. The plates were flicked and washed five times with water and then air-dried. Subsequently, $100 \mu \mathrm{l}$ of the SRB solution in $1 \%$ glacial acetic acid was added and incubated for $30 \mathrm{~min}$ at room temperature. After incubation, plates were washed five times with $1 \%$ acetic acid, air dried and $10 \mathrm{mM}$ Tris base (Sigma Aldrich, India), was added. The absorbance was measured using microplate reader (BioTeK Synergy $\mathrm{H} 1 \mathrm{Hybrid}$ Reader) at $540 \mathrm{~nm}$ wavelength ${ }^{[16]}$.

Data represented the results of three independent experiments. Standard deviation was calculated using Microsoft Excel. Whereas, the P value was calculated with the help of GraphPad Quick-Calcs: $t$ test calculator available freely online ${ }^{[17]}$. All data are presented as a mean value with its standard deviation (mean $\pm \mathrm{SD}$ ).

Hydrodistillation of oil was carried out in the laboratory using Clevenger apparatus. The sample afforded essential oil with pale yellow colour and a characteristic fragrance (yield was $0.02 \%$; $\mathrm{mfb}$ is $0.14 \%$ ). The essential oil was characterized by GCMS and quantified by GC (fig. 2). Twenty seven constituents were identified representing $91.2 \%$ of the total oil. The major constituents were $\beta$-myrcene (65.9 \%), $\alpha$-pinene $(3.1 \%)$, cryptone $(2.0 \%)$, limonene $(1.7 \%)$, sabinene $(0.3 \%), \alpha$-copaene (1.5\%), $\alpha$-humulene $(1.5 \%)$ and $\beta$-phellandrene $(8.8 \%)$. The presence of $\beta$-myrcene is also confirmed by ${ }^{13} \mathrm{C}$ NMR. $\beta$-myrcene and $\beta$-phellandrene were found to be the main constituents from this plant. Moreover the list of essential oil components is documented in Table 1. Earlier reports on essential oil composition of different parts (roots, flowers and aerial parts) of $C$. crepidioides collected from Western Ghats region of India showed that flowers and aerial parts were dominated by monoterpene hydrocarbons with myrcene and $\beta$-phellandrene as major constituents. The other constituents in flower oil were dauca-5,8-diene $(6.9 \%)$, trans- $\beta$-farnesene $(4.8 \%)$, daucene $(3.6 \%)$, allo-aromadendrene (4.9\%), $\alpha$-muurolene $(2.6 \%)$ and $\beta$-panasinsene $(2.4 \%)^{[6]}$. The roots oil of $C$. crepidioides dominated by sesquiterpene hydrocarbons. The main constituents analysed were (E)- $\beta$-farnesene $(30.6 \%)$, $\alpha$-humulene (10.3\%), $\beta$-caryophyllene (7.2\%), cis$\beta$-guaiene $(6.1 \%)$ and $\alpha$-bulnesene $(5.3 \%)^{[18]}$. In our study done on flowering aerial parts from western Himalaya, the major allo-aromadendrene, $\alpha$-muurolene, $\beta$-panasinsene, cis- $\beta$-guaiene and $\alpha$-bulnesene were absent. However, $\beta$-myrcene and $\beta$-phellandrene were found in high concentration. Differences in chemical constituents might occur due to climate, temperature 
and altitudinal variations. Both major compounds found in this study were extensively studied and reported to be pharmacologically active. $\beta$-myrcene is a monoterpene hydrocarbon and reported to possess diverse bioactivities such as antiulcer ${ }^{[19]}$, antimicrobial, antioxidant ${ }^{[20]}$, insect repellent ${ }^{[21]}$, useful for improving flavour of healthcare foods and beverages ${ }^{[22]}$. Moreover, $\beta$-myrcene demonstrated as antiinvasive effect against MDA-MB-231 human breast cancer cells. Also $\beta$-myrcene was reported to inhibit tumor necrosis factor- $\alpha$ (TNF- $\alpha)$-induced nuclear factor- $\kappa \mathrm{B}$ $(\mathrm{NF}-\kappa \mathrm{B})$ activity.Pretreatmentwith $\beta$-myrcenesupressed TNF- $\alpha$-induced phosphorylation of inhibitor of $\kappa B$ kinase and NF- $\mathrm{KB}$ as well as matrix metalloproteinase -9 gene expression in a dose-dependent manner ${ }^{[23]}$. The second major monoterpene hydrocarbon $\beta$-phellandrene also exhibited cytotoxic effect against human breast cancer cell lines. Chemical composition of essential oils (including $\beta$-phellandrene) of Schinus terebinthifolius Raddi and Schinus molle L. berries showed antioxidant and anticancer activity against human breast cancer cell lines $\left(\mathrm{IC}_{50}=47+/-9 \mathrm{mg} / 1, \mathrm{IC}_{50}=5+/-10 \mathrm{mg} / \mathrm{l}\right.$, respectively ${ }^{[24]}$. Therefore, the literature indicated that both $\beta$-myrcene and $\beta$-phellandrene to be cytotoxic. Hence the anticancer activity of $C$. crepidioides against three human cell lines (SiHa, KB and Colo-205) was investigated. In the present study, essential oil of C. crepidioides showed activity against $\mathrm{SiHa}$ cells at 50 and $100 \mu \mathrm{g} / \mathrm{ml}$ (54.9 \pm 0.8 and $59.8 \pm 3.7 \%$, respectively) with $\mathrm{IC}_{50}$ value of $45.9 \mu \mathrm{g} / \mathrm{ml}$. However, it showed significant activity on $\mathrm{KB}$ cells $(67.9 \pm 0.5 \%)$ at
$100 \mu \mathrm{g} / \mathrm{ml}$ with $\mathrm{IC}_{50}$ value of $70.4 \mu \mathrm{g} / \mathrm{ml}$. In case of Colo-205 cells, it was activity at $100 \mu \mathrm{g} / \mathrm{ml}(84.5 \pm$ $3.6 \%$ ) with $\mathrm{IC}_{50}$ value of $41.0 \mu \mathrm{g} / \mathrm{ml}$ (Table 2). The $\mathrm{IC}_{50}$ values of $C$. crepidioides oil ranged between 41.0 to $70.4 \mu \mathrm{g} / \mathrm{ml}$. In literature, extract of $C$. crepidioides showed good anticancer activity and delayed tumor growth in S-180-bearing mice. However, it did not inhibit S-180 cell growth in vitro ${ }^{[3]}$. C. crepidioides at a concentration of $100 \mu \mathrm{g} / \mathrm{ml}$ was non-toxic against MRC-5 and HepG2 cell lines. At the concentration of $25 \mu \mathrm{g} / \mathrm{ml}$ it produced $69.47 \%$ cytoprotection ${ }^{[25]}$. C. crepidioides oil exhibited cytotoxic activity at higher concentrations on all the cells, which varied in a concentration-dependent manner. It can be concluded that essential oil of $C$. crepidioides could further be explored in vivo as a potential an anticancer agent.

In conclusion, these results showed that $C$. crepidioides to be a rich source of monoterpene hydrocarbons, it contained $\beta$-myrcene and $\beta$-phellandrene as major constituents. In recent years, natural compounds and extracts had been shown active against cancer and adopted frequently for the prevention of carcinogenesis. Also presence of medicinally-active $\beta$-myrcene and $\beta$-phellandrene in air will make a clean environment ${ }^{[26]}$. As discussed above based on the results obtained, it could be concluded that $C$. crepidioides essential oil needs to be investigated for detailed anticancer activity and since the essential oil yield is good, it possesses scope of utilization for improving flavour of healthcare foods and beverages as well.

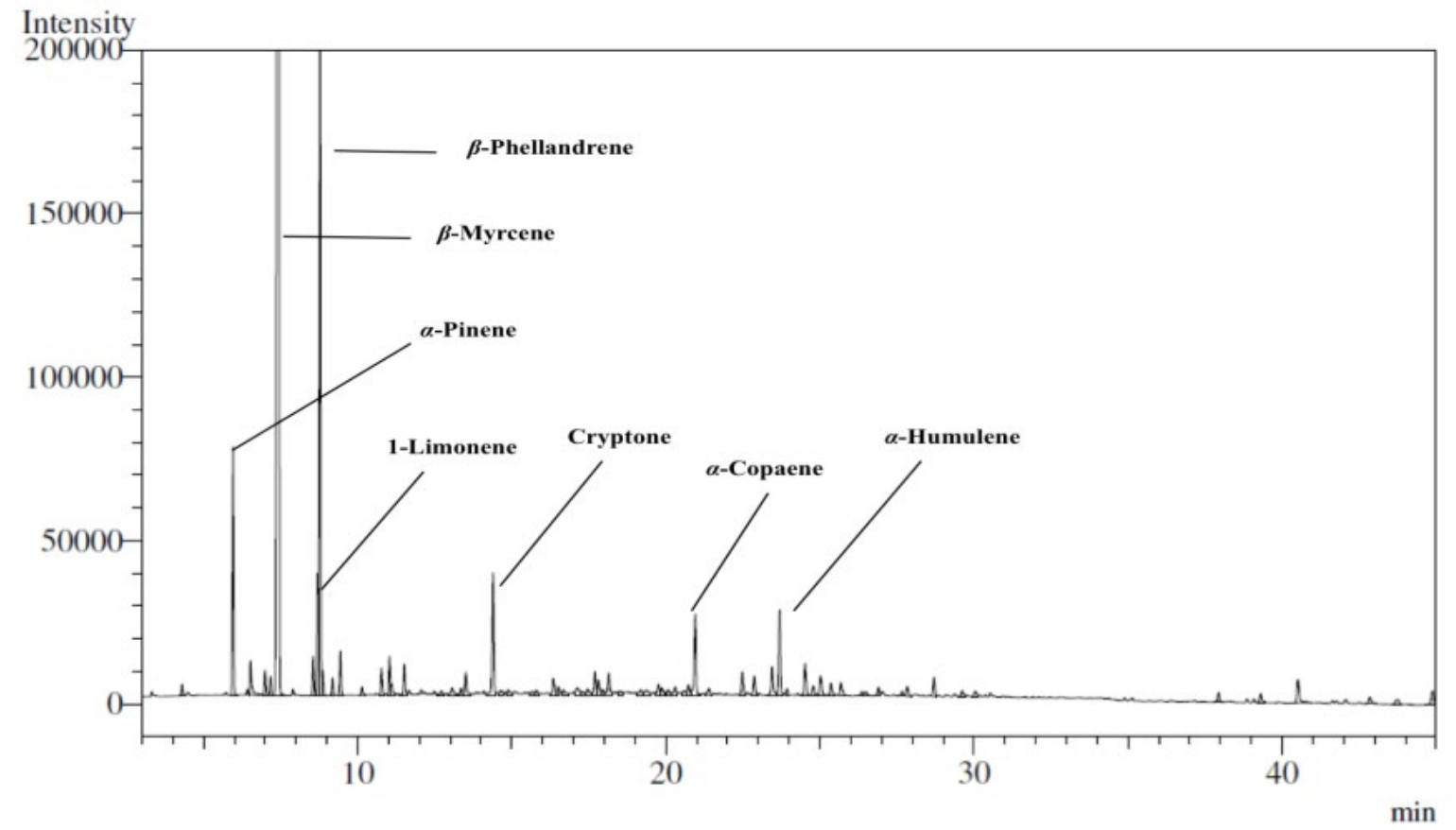

Fig. 2: GC-MS chromatogram of $C$. crepidioides 
www.ijpsonline.com

TABLE 1: CHEMICAL COMPOSITION OF ESSENTIAL OIL OF C. CREPIDIOIDES.

\begin{tabular}{|c|c|c|c|c|c|}
\hline S.No & Component & RI (lit.) & RI (calculated GC) & Area \% & Mode of identification \\
\hline 1 & a-Pinene & 932 & 941 & 3.1 & $\mathrm{RI}, \mathrm{MS}$ \\
\hline 2 & Sabinene & 976 & 979 & 0.3 & RI, MS \\
\hline 3 & B-Pinene & 980 & 985 & 0.3 & $\mathrm{RI}, \mathrm{MS}$ \\
\hline 4 & B-Myrcene & 991 & 994 & 65.9 & $\mathrm{RI}, \mathrm{MS},{ }^{13} \mathrm{C}$ NMR \\
\hline 5 & Cyclooctyne & - & 999 & 0.4 & MS \\
\hline 6 & p-Cymene & 1028 & 1032 & 0.5 & $\mathrm{RI}, \mathrm{MS}$ \\
\hline 7 & Limonene & 1031 & 1037 & 1.7 & $\mathrm{RI}, \mathrm{MS}$ \\
\hline 8 & B-Phellandrene & 1031 & 1039 & 8.8 & RI, MS \\
\hline 9 & B-Ocimene & 1048 & 1051 & 0.2 & $\mathrm{RI}, \mathrm{MS}$ \\
\hline 10 & Perillone & 1102 & 1103 & 0.6 & $\mathrm{RI}, \mathrm{MS}$ \\
\hline 11 & Mentha-2-en-1-ol ‘cis-para> & 1121 & 1118 & 0.5 & $\mathrm{RI}, \mathrm{MS}$ \\
\hline 12 & Cryptone & 1183 & 1196 & 2 & $\mathrm{RI}, \mathrm{MS}$ \\
\hline 13 & Cumic aldehyde & 1239 & 1253 & 0.3 & $\mathrm{RI}, \mathrm{MS}$ \\
\hline 14 & Bornyl acetate & 1285 & 1289 & 0.4 & RI, MS \\
\hline 15 & Terpinen-7-al & 1287 & 1291 & 0.3 & $\mathrm{RI}, \mathrm{MS}$ \\
\hline 16 & a-Copaene & 1376 & 1382 & 1.5 & RI, MS \\
\hline 17 & B-Elemene & 1391 & 1394 & 0.2 & RI, MS \\
\hline 18 & trans-Caryophyllene & 1418 & 1427 & 0.4 & $\mathrm{RI}, \mathrm{MS}$ \\
\hline 19 & a-Bergamotene & 1436 & 1439 & 0.4 & $\mathrm{RI}, \mathrm{MS}$ \\
\hline 20 & a-Humulene & 1454 & 1464 & 1.5 & RI, MS \\
\hline 21 & Germacrene D & 1480 & 1488 & 0.6 & RI, MS \\
\hline 22 & a-Selinene & 1494 & 1503 & 0.4 & $\mathrm{RI}, \mathrm{MS}$ \\
\hline 23 & Apofarnesol & 1496 & 1496 & 0.2 & RI, MS \\
\hline 24 & $\delta$-Cadinene & 1524 & 1525 & 0.3 & RI, MS \\
\hline 25 & Caryophyllene oxide & 1581 & 1588 & 0.1 & RI, MS \\
\hline 26 & Humulene epoxide II & 1606 & 1593 & 0.2 & RI, MS \\
\hline 27 & Cubenol & 1642 & 1653 & 0.1 & RI, MS \\
\hline Total & & & & 91.2 & \\
\hline \multicolumn{3}{|c|}{ Monoterpene hydrocarbons } & & 80.9 & \\
\hline \multicolumn{3}{|c|}{ Sesquiterpene hydrocarbons } & & 4.8 & \\
\hline \multicolumn{3}{|c|}{ Oxygenated sesquiterpenes } & & 0.7 & \\
\hline \multicolumn{3}{|c|}{ Oxygenated monoterpenes } & & 1 & \\
\hline \multicolumn{3}{|c|}{ Others } & & 3.8 & \\
\hline
\end{tabular}

TABLE 2: IN VITRO CYTOTOXICITY AGAINST SiHa, KB AND COLO-205 CELLS BY SRB ASSAY

\begin{tabular}{lcccc}
\hline Sample & Concentration & SiHa & KB & Colo-205 \\
\hline Essential oil of & $10 \mu \mathrm{g} / \mathrm{ml}$ & $7 \pm 4.7$ & $4.2 \pm 1.1$ & $8.5 \pm 2.6$ \\
Crassocephalum & $25 \mu \mathrm{g} / \mathrm{ml}$ & $25.2 \pm 2.7$ & $11.5 \pm 2.6$ & $15.6 \pm 3.7$ \\
crepidioides & $50 \mu \mathrm{g} / \mathrm{ml}$ & $54.9 \pm 0.8$ & $37.7 \pm 0.4$ & $69.4 \pm 4.7$ \\
& $100 \mu \mathrm{g} / \mathrm{ml}$ & $59.8 \pm 3.7$ & $67.9 \pm 0.5$ & $84.5 \pm 3.6$ \\
Vinblastin & $1 \mu \mathrm{M} / \mathrm{ml}$ & $76.0 \pm 1.3$ & $53.0 \pm 0.6$ & $72.5 \pm 2.6$ \\
P value & & $<0.002$ & $<0.001$ & $<0.3$ \\
$\mathrm{IC}_{50}$ value & & $45.9 \mu \mathrm{g} / \mathrm{ml}$ & $70.4 \mu \mathrm{gl} / \mathrm{ml}$ & $41.0 \mu \mathrm{gl} / \mathrm{ml}$ \\
\hline
\end{tabular}

\section{Acknowledgements:}

The authors gratefully acknowledge The Director, CSIR-Institute of Himalayan Bioresource Technology, for continuous support and providing necessary facilities. The authors thank Mrs. Vijaylata Pathania for providing GC and GC-MS data and Mr. Shiv Kumar for NMR data. The authors are also wish to thank the CSIR, New Delhi, for funding BSC-0106, MLP-0066 and MLP-0203 projects.

\section{Conflicts of interest:}

The authors declare that there is no conflict of interests in this paper. 


\section{Financial support and sponsorship:}

CSIR, New Delhi sponsored BSC-0106, MLP-0066 and MLP-0203 projects.

\section{REFERENCES}

1. Taiwe GS, Bum EN, Talla E, Dimo T, Sidiki N, Dawer A, et al. Evaluation of antinociceptive effects of Crassocephalum Bauchiense Hutch (Asteraceae) leaf extract in rodents. J Ethanopharmacol 2012;141:234-41.

2. Hajra PK, Rao RR, Singh DK, Uniyal BP. Flora of India. 13th ed. Kolkata: BSI Publication; 1995. p. 217.

3. Tomimori K, Nakama S, Kimura R, Tamaki K, Ishikawa C, Mori N. Antitumor activity and macrophage nitric oxide producing action of medicinal herb, Crassocephalum crepidiodes. BMC Complement Altern Med 2012;12:78.

4. Omotayo MA, Avungbeto O, Sokefun OO, Eleyowo OO. Antibacterial activity of Crassocephalum crepidioides (Fireweed) and Chromolaena odorata (Siam weed) hot aqueous leaf extract. Int J Pharm Bio Sci 2015;5:114-22.

5. Adjatin A, Dansi A, Badoussi E, Loko YL, Dansi M, Azokpota $\mathrm{P}$, et al. Phytochemical screening and toxicity studies of Crassocephalum rubens (Juss. ex Jacq.) S. Moore and Crassocephalum crepidioides (Benth.) S. Moore consumed as vegetable in Benin. J Chem Pharm Sci 2013;5(6):160-7.

6. Joshi RK. Terpene composition of Crassocephalum crepidioids from Western Ghats region of India. Int J Nat Prod Res 2011;1:19-22.

7. Koundal R, Rawat K, Agnihotri VK, Meena R, Chand G, Singh $\mathrm{RD}$, et al. Temporal and spatial variation in quality of essential oil of Hedychium spicatum and evaluation of its antioxidant activity. J Essent Oil Res 2015;27:217-24.

8. Koundal R, Kumar A, Thakur S, Agnihotri VK, Chand G, Singh RD. Seasonal variation in phytochemicals of essential oil from Juniperus communis needles in western Himalaya. J Essent Oil Res 2015;27:406-11.

9. Koundal R, Kumar D, Walia M, Kumar A, Thakur S, Chand G, et al. Chemical and in vitro cytotoxicity evaluation of essential oil from Eucalyptus citriodora fruits growing in Northwestern Himalaya (India). Flavour Fragr J 2016;31:158-62.

10. Stein SE. Mass spectral Database and Software. Version 3. 02. Gaitherburg, MD: National Institute of standards and Technology (NIST); 1990.

11. Adams RP. Identification of essential oil components by Gas Chromatography/Mass spectroscopy. Carol stream, IL: Allured Publ. Crop.; 2007.

12. Ferreira MJP, Emerencianoa VP, Linia GAR, Romoff P, Macari PAT, Rodrigues GV. ${ }^{13} \mathrm{C}$ NMR spectroscopy of monoterpenoids. Prog Nucl Magn Reson Spectrosc 1998;33:153-06.

13. Kubeczka KH, Formacek V. Essential oils Analysis by
Capillary Gas Chromatography and Carbon-13 NMR Spectroscopy. New York: Wiley; 2002.

14. Srivastava S, Misra A, Kumar D, Srivastava A, Sood A, Rawat A. Reversed-phase high-performance liquid chromatographyultraviolet photodiode array detector validated simultaneous quantification of six bioactive phenolic acids in Roscoea purpurea tubers and their In vitro cytotoxic potential against various cell lines. Pharmacogn Mag 2015;11:488-95.

15. Guliani A, Kumari A, Kumar D, Yadav SK. Development of nanoformulation picroliv isolated from Picrorrhiza kurroa. IET Nanobiotechnol 2015.0032:6.

16. Kumar D, Sukapaka M, Kiran Babu GD, Padwad Y. Chemical Composition and In Vitro Cytotoxicity of Essential Oils from Leaves and Flowers of Callistemon citrinus from Western Himalayas. Plos One 2015;10(8):e0133823.

17. QuickCalcs. t Test calculator. Available from: http://www. graphpad.com/quickcalcs/ttest1/? Format=SD.

18. Joshi RK. Study on essential oil composition of the roots of C. crepidioids (BENTH.) S. Moore. J Chil Chem Soc 2014;59:2363-5.

19. Bonamin F, Moraes TM, Dos Santos RC, Kushima H, Faria FM, Silvia MA, et al. The effect of a minor constituent of essential oil from Citrus aurantium: The role of beta-myrcene in preventing peptic ulcer disease. Chem Biol Interact 2015;212:11-9.

20. Donati M, Mondin A, Chen Z, Miranda FM, do Nascimento BB Jr, Schirato G, et al. Radical scavenging and antimicrobial activities of Croton zehntneri, Pterodon amarginatus and Schinopsis brasiliensis essential oils and their major constituents: estragole, trans-anethole, beta-caryophyllene and myrcene. Nat Prod Res 2015;29:939-46.

21. Yong H, Tingting C, Jianping Q, Bin Y. Floral mosquito repelling ink. Patent no. CN103642301A. 2014 March 19.

22. Fei Q, Zhiguo P, Hanqing C, Wang R, Chen Y. Rosin type mango essence and application thereof. Patent no. CN104543930A. 2015 April 29.

23. Lee JH, Lee K, Lee DH, Shin SY, Yong Y, Lee YH. Antiinvasive effect of beta-myrcene, a component of the essential oil from Pinus koraiensis cones, in metastatic MDA-MB-231 human breast cancer cells. J Korean Soc Appl Biol Chem 2015;58:563-9.

24. Bendaoud H, Romdhane M, Souchard JP, Cazaux S, Bouajila J. Chemical composition and anticancer and antioxidant activityes of Schinus molle L. and Schinus terebinthifolius Raddi berries essential oils. J Food Sci 2010;75(6):C466-72.

25. Sumi W, Nee TK, Jin KT, Mustafa DW, Christophe W. Antioxidant, anti-inflammatory, cytotoxicity, and cytoprotection activities of Crassocephalum crepidioides (Benth.) S. Moore. extracts and its phytochemical composition. Eur J Sci Res 2011;67(1):157.

26. Agnihotri VK. Anabaena flos-aquae. Crit Rev Environ Sci Tech 2014;44:1995-2037. 